\title{
Growth, biomass, and production of two small barbs (Barbus humilis and B. tanapelagius, Cyprinidae) and their role in the food web of Lake Tana (Ethiopia)
}

\author{
Eshete Dejen · Jacobus Vijverberg • \\ Leopold A. J. Nagelkerke • \\ Ferdinand A. Sibbing
}

Received: 3 December 2008/Revised: 24 August 2009/Accepted: 7 September 2009/Published online: 19 October 2009

(C) The Author(s) 2009. This article is published with open access at Springerlink.com

\begin{abstract}
Growth, biomass and production of two small barbs (Barbus humilis and Barbus tanapelagius) and their role in the food web of Lake Tana were investigated. From length-frequency distribution of trawl monitoring surveys growth coefficient, $\Phi^{\prime}$ values were estimated at $3.71-4.17$ for $B$. humilis and 3.70-4.14 for B. tanapelagius, respectively. Values for $B$. humilis were confirmed in pond experiments. Mean biomass of the small barbs was $13.3 \mathrm{~kg}$ fresh wt ha ${ }^{-1}$, with $B$. humilis being most
\end{abstract}

Handling editor: I. Nagelkerken

E. Dejen · F. A. Sibbing

Experimental Zoology Group, Wageningen University,

Wageningen Institute of Animal Sciences, Marijkeweg

40, 6709, PG, Wageningen, The Netherlands

e-mail: Eshete.Dejen@fao.org

Present Address:

E. Dejen

FAO-Sub Regional Office for Eastern Africa,

P.O. Box 5536, Addis Ababa, Ethiopia

J. Vijverberg ( $\square)$

Netherlands Institute of Ecology (NIOO-KNAW), Centre for Limnology, Rijksstraatweg 6, 3631, AC, Nieuwersluis, The Netherlands

e-mail: j.vijverberg@nioo.knaw.nl

L. A. J. Nagelkerke

Aquaculture and Fisheries Group, Wageningen University, Wageningen Institute of Animal Sciences, Marijkeweg 40, 6709, PG, Wageningen, The Netherlands e-mail: Leo.Nagelkerke@wur.nl abundant in the littoral and sub-littoral zones, whereas B. tanapelagius was most abundant in the sub-littoral and pelagic zones. The two small barbs had a production of $53 \mathrm{~kg}$ fresh wt ha ${ }^{-1}$ year $^{-1}$. Although their $P / B$ ratios of about 4.0 were relatively high for small cyprinids, both their biomass and production were low in comparison with other small fish taxa in other tropical lakes. Of the zooplankton production only about $29 \%$ was consumed by the small barbs. However, they did not utilize calanoid copepods, which were responsible for approximately $57 \%$ of the zooplankton production and it is likely that small barb production was food limited during certain periods of the year. Piscivorous labeobarbs consumed about $56 \%$ of the small barbs production annually, but additionally, Clarias gariepinus, and many bird species were also preying on them. Therefore, limitation of Barbus production by predation during certain periods in the year cannot be excluded.

Keywords Africa - Ecosystem · Fishery · Fish production - Lakes Zooplanktivory Zooplankton

\section{Introduction}

Lake Tana is the largest freshwater lake in Ethiopia and source of the Blue Nile River. Commercially important fish species in Lake Tana are an endemic flock of 15 large Labeobarbus spp. (Cyprinidae), Varicorhinus beso Rüppell (Cyprinidae), Nile tilapia, Oreochromis 
niloticus (L.) (Cichlidae) and African catfish, Clarias gariepinus (Burchell) (Clariidae) (Nagelkerke, 1997; de Graaf et al., 2006). In addition, three 'small barb' species (genus Barbus, $<100$ mm length, Cyprinidae), Barbus humilis Boulenger, B. pleurogramma Boulenger and B. tanapelagius de Graaf, Dejen and Osse, as well as three species of the genus Garra (Cyprinidae) have been reported from the lake.

Until recently, studies mainly focussed on the endemic species flock of Labeobarbus in the lake (e.g. Nagelkerke et al., 1994; Sibbing \& Nagelkerke, 2001). Surprisingly, eight of these are piscivores (de Graaf et al., 2008). Studies on the three species of small barbs, B. humilis, B. pleurogramma and B. tanapelagius started only recently (e.g. Dejen et al., 2006a, b). B. tanapelagius is endemic to the L. Tana catchment and common in the large pelagic zone of the lake. B. humilis is a littoral species, while $B$. pleurogramma is mainly present in the wetlands around the lake. B. humilis was assumed to be endemic to Lake Tana too, but was recently collected from the Beshilo River in the Ethiopian Plateau (Eshete Dejen pers. observation).

Small zooplanktivorous fish, mainly cyprinid and clupeid species, are generally characterized by a high growth rate and a prolific reproduction which reduces the chance of overfishing (e.g. Duncan, 1999; Sarvala et al., 2002). Serious decline of the stocks of endemic Labeobarbus species in Lake Tana (de Graaf et al., 2006) raises the question if inclusion of the small zooplanktivorous barbs into the fishery would be realistic and desirable. The feasibility of such a fishery largely depends on the biomass and productivity of the stocks of the small barbs. Therefore, we addressed the following four questions: (1) What is the production of the small barbs in Lake Tana; (2) How does this production compare with other small zooplanktivorous fish in other tropical lakes; (3) Is this production limited by predation and/or food availability and (4) Is the production of the small barbs high enough to start a fishery on these species?

\section{Materials and methods}

Study area

Lake Tana is situated in the north-west of Ethiopia at an altitude of $1,800 \mathrm{~m}$. The lake is turbid and shallow (average depth $8 \mathrm{~m}$, maximum depth $14 \mathrm{~m}$ ) and has a surface area of about $3,150 \mathrm{~km}^{2}$. Based on its chlorophyll content it may be classified as mesotrophic (Dejen et al., 2004), but because of its high turbidity, gross primary production rate (annual average $2.43 \mathrm{~g} \mathrm{O}_{2} \mathrm{~m}^{-2} \mathrm{day}^{-1}$ ) is relatively low (Wondie et al., 2007). It is well-mixed because of wind exposure and its small depth. The shallow, littoral zone (0-4 m depth) is relatively small, about $10 \%\left(315 \mathrm{~km}^{2}\right)$ of the total surface area of the lake. The sub-littoral zone is intermediate in depth (4-8 m) and occupies about $20 \%\left(630 \mathrm{~km}^{2}\right)$ of the lake area, whereas the pelagic zone $(8-14 \mathrm{~m})$ covers $70 \%$ $\left(2,205 \mathrm{~km}^{2}\right)$ of the lake surface area.

Sampling procedure

Fish were sampled at 12 sampling stations in the Southern Gulf of Lake Tana from October 1999 to November 2001 (Fig. 1). The stations represented three habitat types: (a) a shallow, littoral zone with a mixture of mud and silt substratum with submerged vegetation; (b) a sub-littoral zone with mud and silt substratum and (c) a pelagic zone with predominantly inorganic silt substratum.

A bottom trawl was used during dusk and dawn. The net was kept open with a $5 \mathrm{~m}$ beam and was hauled at a speed of $1.0 \mathrm{~m} \mathrm{~s}^{-1}$ in a straight line $50 \mathrm{~m}$ behind a $6.8 \mathrm{~m}$ flat-bottomed polyester boat with a 25 HP outboard engine. The fishing width of the net was estimated to be $3 \mathrm{~m}$ by using thin breakable ropes. The bar mesh sizes varied from 10 to $5.5 \mathrm{~mm}$ from the side panels to the cod end. Hauls lasted $15 \mathrm{~min}$, resulting in 2,700 $\mathrm{m}^{2}$ swept area per haul. For each fish species, total numbers and fresh weight were recorded. A random sub-sample of at least 30 individuals (or all individuals in the sample) was taken for the measurement of fork length (nearest $\mathrm{mm})$.

Growth and mortality estimates

Monthly length-frequency distributions of $B$. humilis and $B$. tanapelagius were collected for 26 consecutive months. Mean length-frequency distributions were produced for January-December. These data were used for the analysis of growth parameters in the FiSAT II computer package (Gayanilo et al., 2002). We applied both a direct analysis of length- 
Fig. 1 Map of Lake Tana showing a the study area and $\mathbf{b}$ the sampling stations in three habitat zones: littoral (L1-L4), sublittoral (S1-S4) and pelagic (P1$\mathrm{P} 4)$
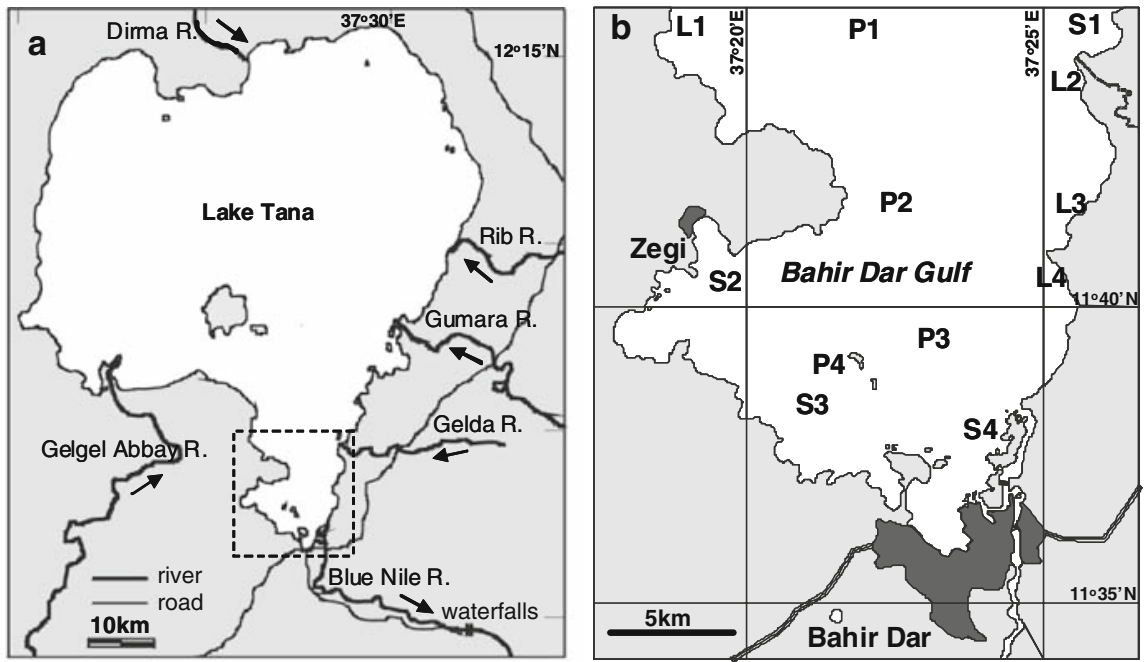

frequency distributions, using the ELEFAN method, as well as more indirect methods based on estimated growth increments. Growth increments were estimated using an adapted version of Bhattacharya's method for the analysis of mixtures of normal distributions, which were then analysed using three methods available in the FiSAT II computer package, i.e. Munro's, Faben's and Appeldoorn's methods (Gayanilo et al., 2002). Since no significant seasonality in growth could be detected, growth was assumed to be described by the von Bertalanffy growth function (VBGF):

$L_{t}=L_{\infty}\left(1-e^{-K\left(t-t_{0}\right)}\right)$,

where $L_{t}$ is length at age $t, L_{\infty}$ is the asymptotic size, $K$ is the growth constant and $t_{0}$ is the hypothetical age at length zero. Estimates of $L_{\infty}$ and $K$ followed the steps, described by Amarasinghe \& De Silva (1992). The value for $t_{0}$ was assumed to be zero.

The Pauly \& Munro (1984) relationship was used to calculate the index of overall growth performance $\Phi^{\prime}$. This index is well suited to compare growth of closely related species (Amarasinghe, 2002).

$\Phi^{\prime}=2 \log L_{\infty}+\log K$.

In addition to catch analyses we estimated growth rate of $B$. humilis experimentally. Mean length increments of seven length classes $(18-80 \mathrm{~mm}$ FL; $n=99)$ were measured in seven outdoor basins (diameter $300 \mathrm{~cm}$, height $100 \mathrm{~cm}$, water depth $50 \mathrm{~cm}$ ) over 30 days. The basins were located in an open shed adjacent to the lake and the sides were covered by nets to prevent piscivorous birds from entering the basin area. Basins were part of an open water flow system. Water was pumped directly from the lake, distributed over the basins and flowed back to the lake. This resulted in a continuous flow of lake water with natural seston and zooplankton concentrations. No food was added. Water temperature, oxygen levels and transparency were similar to lake conditions. As all fish were from the same field population and conditions in all basins were identical, the growth of the fish in the seven basins was assumed to conform to the same pattern. The size classes of $B$. humilis used were: $\mathrm{sc} 1=16-19 \quad(n=14)$, $\mathrm{sc} 2=20-26 \quad(n=14), \quad \mathrm{sc} 3=37-49 \quad(n=19)$, sc4 $=55-59 \quad(n=15), \quad \operatorname{sc5}=65-70 \quad(n=16)$, sc6 $=78-80 \quad(n=17)$, sc7 $=79-81 \quad(n=4)$. Each size class was put in a separate basin and growth increments were determined in each basin separately. Fish were measured at the start $(t=0)$ and at the end ( $t=30$ days $)$ of the experiment.

Total mortality rate $(Z)$ was estimated from a length-converted catch curve using pooled lengthfrequency samples, and is defined by the equation (Pauly, 1984):

$\ln \left(N_{i} / \Delta t_{i}^{\prime}\right)=a+b t_{i}^{\prime}$,

where $N_{i}$ is the number of fish caught in a given length class $i$; $t_{i}^{\prime}$ is the relative age corresponding to length class $i$ and $\Delta t$ ' is the average time needed by the fish to grow through length class $i$. In this case, the estimated total mortality $(Z)$ was equal to the natural mortality $(M)$ since the fishery does not exploit these species. 
Biomass and production estimates

Biomass $(B)$ of the small barbs was estimated by the swept area method (Sparre \& Venema, 1998) from samples taken with the bottom trawl, using:

$B=\frac{C}{w \cdot v \cdot t} \cdot \frac{1}{q}$,

where $C$ is the catch from the haul, $w$ is the fishing width of the trawl net $(3 \mathrm{~m}), v$ is the velocity of the trawl $\left(1 \mathrm{~m} \mathrm{~s}^{-1}\right), t$ is the duration of the haul (usually $15 \mathrm{~min}$ ), and $q$ is the catchability coefficient, or trawling efficiency. The trawl we used had an estimated $q$ of $50 \%$ in sampling $0+$ fish in Dutch lakes (Vijverberg et al., 1990). Since the bottom trawl only fished the deepest $1 \mathrm{~m}$ of the water column we corrected all biomass estimates for the distribution of Barbus humilis and B. tanapelagius in the whole water column. For this purpose, we used simultaneous gillnet surveys, using benthic and pelagic multimesh, monofilament survey gillnets, composed of five randomly distributed panels with 5.0, 6.25, 8.0, 10.0 and $12.5 \mathrm{~mm}$ bar mesh (Dejen et al., 2006a). The abundance of fish at different depths in the gillnet was used to calculate the biomass of fish in the whole water column.

Production of small barbs $(P)$ was estimated using Allen's (1971) assumption that in case of a constant exponential death rate and when Von Bertalanffy growth applies, the production/biomass ratio $(P / B)$ is equal to $Z$, the total instantaneous mortality rate.

Potential zooplanktivorous fish production was also estimated based on the production of zooplankton, the principal food source of the small Barbus species. Zooplankton production was estimated by calculating biomass per species and using relevant $P / B$ ratios given in literature. In addition, we estimated a minimum value of Barbus production, based on the production of their main predators, the piscivorous Labeobarbus species (Wudneh, 1998; de Graaf et al., 2003). We assumed 10\% trophic efficiencies (see, e.g. de Angelis, 1992), and a dry:fresh weight ratio of 1:5 (see, e.g. Post \& Lee, 1996).

\section{Maximum sustainable yield}

In order to evaluate the viability of a fishery on the small Barbus species we estimated the maximum sustainable yield (MSY) according to Sparre \&
Venema (1998) as $M S Y=x \cdot M \cdot B_{v}=x \cdot P$, where $M=$ natural mortality, $B_{v}=$ virgin stock biomass, and $x$ is a constant. According to the original formula of Gulland (1971) $x$ can have a value of 0.5 , but Beddington \& Cooke (1983) concluded that this generally overestimates MSY by a factor $2-3$, so that a value of 0.2 would result in a more realistic estimate of MSY (Sparre \& Venema, 1998).

\section{Results}

Growth and mortality estimates

From the trawl survey, we monthly collected a mean number of 7,408 $(\mathrm{SD}=4,750)$ and 1,887 $(\mathrm{SD}=3,065)$ specimens of $B$. humilis and B. tanapelagius, respectively. It was found that both species are small $(<100 \mathrm{~mm}$ FL) and that females grow to a larger size than males. The maximum length recorded was 96 and $89 \mathrm{~mm}$ fork length (FL) for B. humilis and B. tanapelagius, respectively. Mean length (FL) and standard deviations ( $\pm \mathrm{SD}$ ) from length-frequency data were $63.2 \pm 8.5 \mathrm{~mm}$ (females, $n=4,852$ ) and $55.6 \pm 6.6 \mathrm{~mm}$ (males, $n=1,401$ ) for B. humilis specimens and $58.6 \pm 7.9 \mathrm{~mm}$ (females, $n=2,925$ ) and $53.3 \pm 5.5 \mathrm{~mm}$ (males, $n=1,041$ ) for $B$. tanapelagius. Length-weight relationships (FL in mm; fresh weight (W) in gram) were calculated for $B$. humilis $\left(W=1.97 \times 10^{-5} \mathrm{FL}^{2.898}\right.$; $\left.n=4,886 ; \quad r^{2}=0.92\right)$, and for $B$. tanapelagius $\left(W=1.54 \times 10^{-5} \mathrm{FL}^{2.919} ; n=2,926 ; r^{2}=0.91\right)$.

Based on the analyses of length-frequency distributions (Fig. 2) we estimated $L_{\infty}$ to range between 79 and $91 \mathrm{~mm}$ for $B$. humilis and between 71 and $98 \mathrm{~mm}$ for $B$. tanapelagius, respectively (Fig. 2). $K$ ranged between 0.73 and 2.36 year $^{-1}$ for $B$. humilis, and between 0.66 and 2.33 year $^{-1}$ for $B$. tanapelagius. Values of the growth index $\left(\Phi^{\prime}\right)$ varied less, ranging between 3.71 and 4.17 for $B$. humilis and 3.70 and 4.14 for $B$. tanapelagius. These length-based estimates of growth parameters were confirmed by results from direct growth measurement of $B$. humilis in outdoor basins. Using the Gulland and Holt method (Sparre \& Venema, 1998) we found that the growth constant $K$ was 1.50 year $^{-1}$ and $L_{\infty}$ was $88.4 \mathrm{~mm}$ FL (Fig. 3), resulting in a growth index $\left(\Phi^{\prime}\right)$ of 4.07 which falls in the range of the estimates for the field population of this species. 
Fig. 2 Restructured length-frequency distributions of $B$. humilis (top) and B. tanapelagius (bottom)
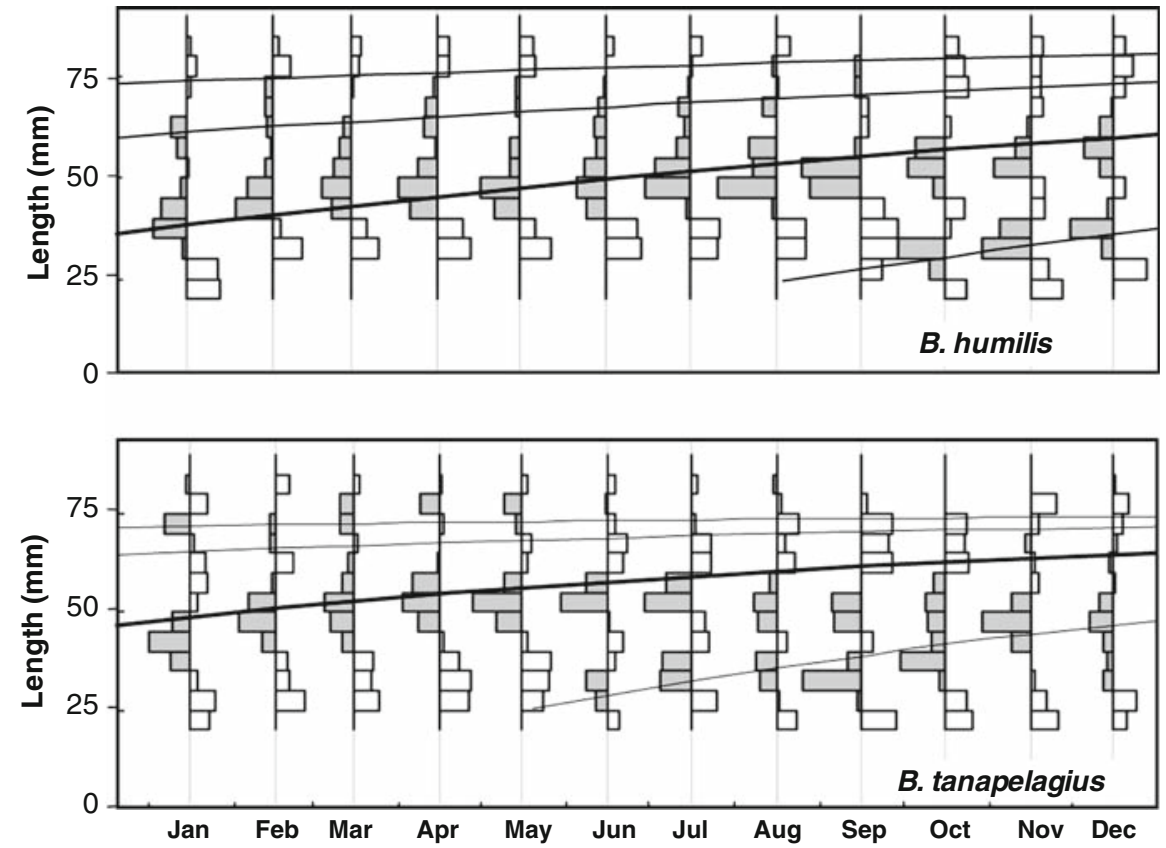

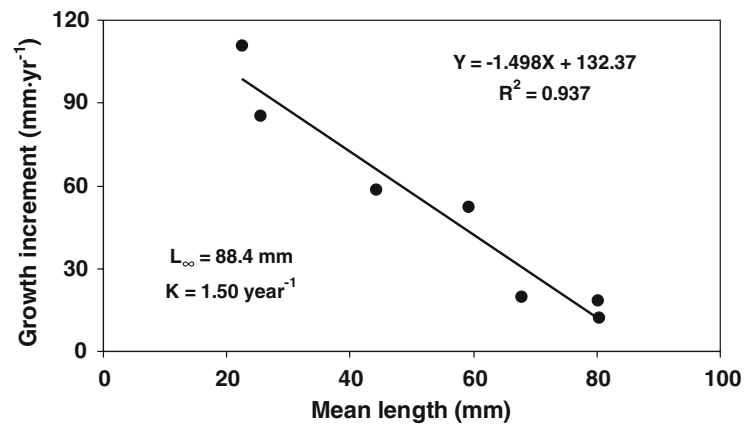

Fig. 3 Outdoor basin growth measurement on B. humilis. Mean length increase in mm over one year relative to the mean size per size class $\left(\left(L_{t=0}+L_{t=30}\right) / 2\right)$. Each size class was introduced to a separate pool. The size classes and the number of fish measured were: $\mathrm{sc} 1=16-19(n=14), \mathrm{sc} 2=20-26$ (14), sc3 = 37-49 (19), sc4 = 55-59 (15), sc5 = 65-70 (16), sc6 $=78-80$ (17), sc7 $=79-81$ (4). Note that growth increment within 30 days $(=0.0822$ year) was expressed on a yearly basis in order to establish $L_{\infty}$ and $K$ from the slope and intercept

Estimated total mortality $(Z)$ ranged between 3.9 and 4.3 year $^{-1}$ for B. humilis and between 3.1 and 4.7 for B. tanapelagius, respectively (Fig. 4).

Biomass and production estimates

Biomass of the small barb species differed between species and habitats. B. humilis was most abundant in the sub-littoral zone of intermediate depth (mean value of $23.5 \mathrm{~kg}$ fresh wt ha ${ }^{-1}$ ), less abundant in the littoral, shallow area $\left(9.2 \mathrm{~kg}\right.$ fresh $\left.\mathrm{wt} \mathrm{ha}^{-1}\right)$ and almost absent from the pelagic, deeper pelagic zone (0.2 kg fresh wt ha ${ }^{-1}$; Fig. 5). When weighted for the relative area of each habitat this amounts to a mean biomass of $5.8 \mathrm{~kg}$ fresh wt ha ${ }^{-1}$ for $B$. humilis in the lake as a whole (Table 1). B. tanapelagius was most abundant in the deeper pelagic zone $(9.2 \mathrm{~kg}$ fresh $\left.\mathrm{wt} \mathrm{ha}^{-1}\right)$, less abundant in the sub-littoral zone (5.1 kg fresh wt ha ${ }^{-1}$ ), although in 1999 this was not the case, and virtually absent from the littoral, shallow parts of the lake (0.4 kg fresh ha ${ }^{-1}$; Fig. 5). When weighted for the relative area of each habitat the biomass of $B$. tanapelagius was estimated at $7.5 \mathrm{~kg} \cdot$ fresh wt ha ${ }^{-1}$ for the whole lake (Table 1).

Annual production of $B$. humilis was $23.7 \mathrm{~kg}$ fresh wt ha ${ }^{-1}$.year ${ }^{-1}$, based on a $P / B$ ratio of 4.1 . For B. tanapelagius the annual production is $29.2 \mathrm{~kg} \cdot \mathrm{fresh}$ wt ha ${ }^{-1}$ year $^{-1}$ given a $P / B$ ratio of 3.9 (Table 1 ). Total annual production of both small barb species in Lake Tana is estimated at $52.9 \mathrm{~kg} \cdot f r e s h ~ w t ~ h a^{-1}$ year $^{-1}$ or $16,700 \mathrm{t}$ fresh wt year ${ }^{-1}$.

The MSY for the whole of Lake Tana was estimated to be $4.7 \mathrm{~kg}$ fresh wt ha ${ }^{-1}$ year $^{-1}\left(1,500 \mathrm{t} \mathrm{year}^{-1}\right)$ for B. humilis and $6.1 \mathrm{~kg}$ fresh wt ha ${ }^{-1}$ year $^{-1}(1,900$ $\mathrm{t}$ fresh wt year $^{-1}$ ) for B. tanapelagius (Table 1), using $\mathrm{MSY}=0.2 M \cdot B_{v}=0.2 P($ Sparre \& Venema, 1998) 

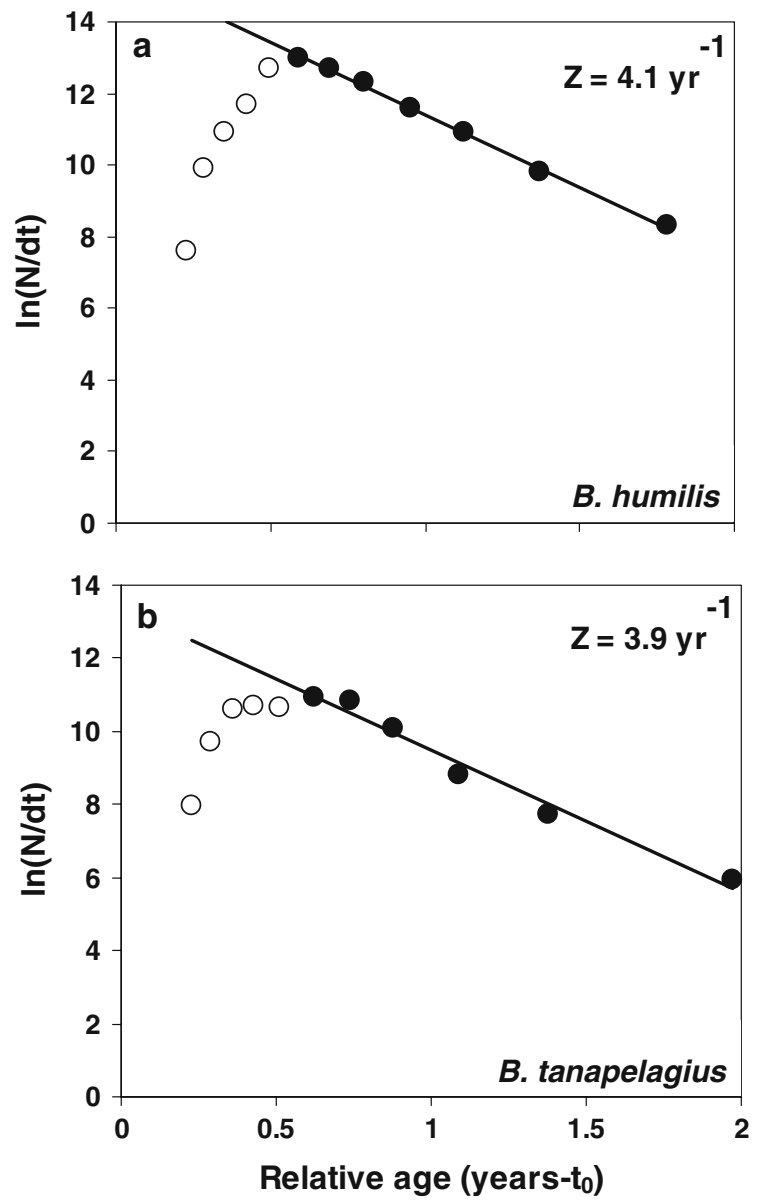

Fig. 4 Length-converted catch curve for B. humilis (a) and B. tanapelagius (b). The slope of the regression line gives the estimate for $\mathrm{Z}$

Limiting factors for the Barbus production

In order to estimate potential zooplanktivorous fish production, we calculated the production of zooplankton in Lake Tana (Table 2) using densities and length-frequency distributions of the different zooplankton species given by Dejen et al. (2004) and length-weight regressions given by Amarasinghe et al. (1997). The relationships between $P / B$ ratios and the size of the zooplankton species were taken from Amarasinghe et al. (2008). Assuming a mean water depth of $8 \mathrm{~m}$, this resulted in an estimated biomass of $11.5 \mathrm{~kg}$ dry wt ha ${ }^{-1}$ and an annual zooplankton production of $370 \mathrm{~kg}$ dry $\mathrm{wt} \mathrm{ha}^{-1}$ year $^{-1}$ (Table 2). Assuming a $10 \%$ trophic efficiency, and a dry:fresh weight ratio of 1:5 for fish, this resulted in a potential zooplanktivorous fish

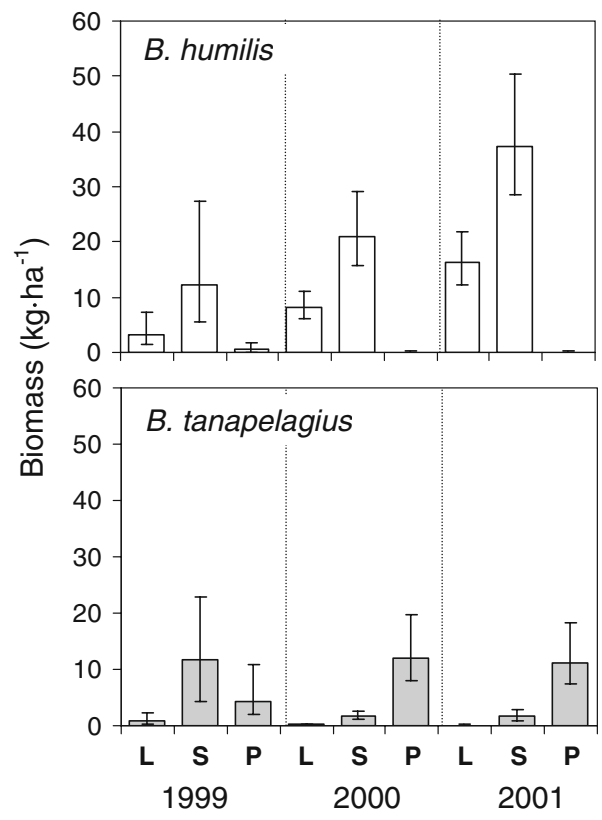

Fig. 5 Mean biomass $\left(\mathrm{kg} \mathrm{ha}^{-1}\right)$ for the two small barbs (B. humilis and B. tanapelagius) at three habitats; littoral (L), sublittoral (S), and pelagic (P) in three successive years (19992001). Error bars represent $95 \%$ confidence intervals

production of $185 \mathrm{~kg} \mathrm{ha}^{-1}$ year $^{-1}$. Since the total small barb production was only $52.9 \mathrm{~kg}$ fresh wt ha ${ }^{-1}$ year $^{-1}$ (Table 1), this would mean that they only consume a small proportion (about 29\%) of the total zooplankton production.

The piscivorous Labeobarbus species accounted for $12 \%\left(3.8 \mathrm{~kg} \mathrm{ha}^{-1} \mathrm{year}^{-1}\right)$ of the total annual Labeobarbus production ( $32 \mathrm{~kg} \mathrm{ha}^{-1}$ year $^{-1}$ ) (Wudneh, 1998). Assuming a $10 \%$ trophic conversion efficiency, these predators would need approximately $38 \mathrm{~kg} \mathrm{ha}^{-1}$ year $^{-1}$ of prey fish production. Since the small barbs account for about $75 \%$ of their diet (de Graaf et al., 2008) this would mean that annually about $29 \mathrm{~kg}$ fresh wt ha ${ }^{-1}$ of small barbs are eaten by the piscivorous labeobarbs.

\section{Discussion}

\section{Methodology}

Length-based models are always a bit suspect and there are more modern methods available than those provided by Fisat II (see, e.g. Fournier et al., 1998). However, we decided to use the variety of techniques 
Table 1 Biomass, production and maximum sustainable yield (MSY) of two small Barbus species from Lake Tana (fresh wt.)

\begin{tabular}{|c|c|c|c|}
\hline & $\begin{array}{l}\text { B. humilis } \\
\text { Mean (low-high) }\end{array}$ & $\begin{array}{l}\text { B. tanapelagius } \\
\text { Mean (low-high) }\end{array}$ & $\begin{array}{l}\text { Total } \\
\text { Mean (low-high) }\end{array}$ \\
\hline Biomass $\left(\mathrm{kg} \cdot \mathrm{ha}^{-1}\right)$ & $5.8(4.0-9.0)$ & $7.5(4.5-13.4)$ & $13.3(8.5-22.4)$ \\
\hline Biomass $(\times 1,000 \mathrm{t})$ & $1.8(1.3-2.8)$ & $2.4(1.4-4.2)$ & $4.2(2.7-7.0)$ \\
\hline $\mathrm{Z}\left(\right.$ year $\left.^{-1}\right) \approx P / B$ & $3.9-4.3$ & $3.1-4.7$ & \\
\hline Production $\left(\mathrm{kg} \mathrm{ha}^{-1}\right.$ year $\left.^{-1}\right)$ & $23.7(15.6-38.8)$ & $29.2(13.9-62.7)$ & $52.9(29.5-101.5)$ \\
\hline Production $\left(\times 1,000 \mathrm{t} \mathrm{year}^{-1}\right)$ & $7.5(4.9-12.2)$ & $9.2(4.4-19.8)$ & $16.7(9.3-32.0)$ \\
\hline $\operatorname{MSY}\left(\mathrm{kg} \mathrm{ha}^{-1}\right.$ year $\left.^{-1}\right)$ & $4.7(3.3-7.4)$ & $6.1(3.7-10.9)$ & $10.9(7.0-18.3)$ \\
\hline $\operatorname{MSY}\left(\times 1,000 \mathrm{t}\right.$ year $\left.^{-1}\right)$ & $1.5(1.0-2.3)$ & $1.9(1.2-3.4)$ & $3.4(2.2-5.8)$ \\
\hline
\end{tabular}

Indicated are mean estimates and lower (low) and upper (high) 95\% confidence limits

Table 2 Biomass $\left(B, \mathrm{~kg}\right.$ dry wt ha $\left.{ }^{-1}\right)$ and production $\left(P, \mathrm{~kg} \cdot \mathrm{dry} \mathrm{wt} \mathrm{ha}^{-1} \mathrm{year}^{-1}\right)$ of the crustacean zooplankton of Lake Tana

\begin{tabular}{|c|c|c|c|c|c|}
\hline Species & $\begin{array}{l}\text { Average } \\
\text { density }\left(\mathrm{n}^{-1}\right)\end{array}$ & $\begin{array}{l}\text { Average } \\
\text { size }(\mathrm{L} \text { in } \mathrm{mm})\end{array}$ & $B\left(\mathrm{~kg} \mathrm{ha}^{-1}\right)$ & $P\left(\mathrm{~kg} \mathrm{ha}^{-1}\right.$ year $\left.^{-1}\right)$ & $P / B\left(\right.$ year $\left.^{-1}\right)$ \\
\hline Bosmina longirostris & 7.9 & 0.38 & 0.9 & 67.7 & 78 \\
\hline Ceriodaphnia cornuta & 0.2 & 0.31 & 0.0 & 0.7 & 113 \\
\hline Ceriodaphnia dubia & 0.8 & 0.42 & 0.0 & 2.7 & 65 \\
\hline Diaphanosoma spp & 8.0 & 0.77 & 0.6 & 14.5 & 23 \\
\hline Daphnia hyalina & 5.2 & 1.24 & 1.1 & 10.6 & 10 \\
\hline Daphnia lumholtzi & 4.6 & 0.90 & 0.5 & 8.2 & 16 \\
\hline Moina micrura & 1.4 & 0.50 & 0.1 & 7.8 & 155 \\
\hline Mesocyclops aequatorialis & 2.4 & 0.79 & 0.4 & 12.4 & 31 \\
\hline Thermocyclops ethiopiensis & 8.6 & 0.59 & 0.8 & 33.5 & 40 \\
\hline Thermodiaptomus galebi & 17.7 & 0.79 & 7.0 & 212.3 & 30 \\
\hline Total & 56.8 & & 11.5 & 370 & 32.2 \\
\hline
\end{tabular}

Annual $P / B$ ratios were estimated from the relationship between zooplankton length and $P / B$ given by Amarasinghe et al. (2008)

provided by this computer package in order to allow direct comparisons with studies on other tropical systems, which mostly used similar methods. Moreover, the quality of the data would most probably not lead to much better estimates using more sophisticated methods.

The concepts of MSY and biomass estimates by swept area using a trawl are generally not very accurate and represent only rough approximations for potential yield and standing stock biomass and this is also true for our study. The constant ' $x$ ' which determines the MSY is quite arbitrary. Although by using $x=0.2$ our estimates for MSY are conservative, this figure should be regarded with caution. However, we are confident that in this study the use of MSY and biomass estimated by swept area are useful concepts because we apply a four-pronged approach to estimate the sustainability of a fishery on the small barbs: First, the MSY estimate of the small barbs; second, the production estimate of the two barbs and their consumption of zooplankton; third, a production estimate of food organisms of the small barbs and fourth, an estimate of the consumption of small barbs by piscivores.

Biomass and productivity of small fish taxa in tropical lakes

The biomass of the two small Barbus species in Lake Tana (\# TA-6, TA-7 in Fig. 6) of 5.8 and $7.5 \mathrm{~kg} \mathrm{ha}^{-1}$ is low in comparison with the biomass of most other small, predominantly planktivorous, fish taxa in other tropical lakes and reservoirs (Table 3; Fig. 6a). Of the 19 fish taxa reviewed, only five had a similar low biomass: three feeding guilds of haplochromines in Lake Victoria (\# 8, 9, 10), a small cyprinid in Lake 

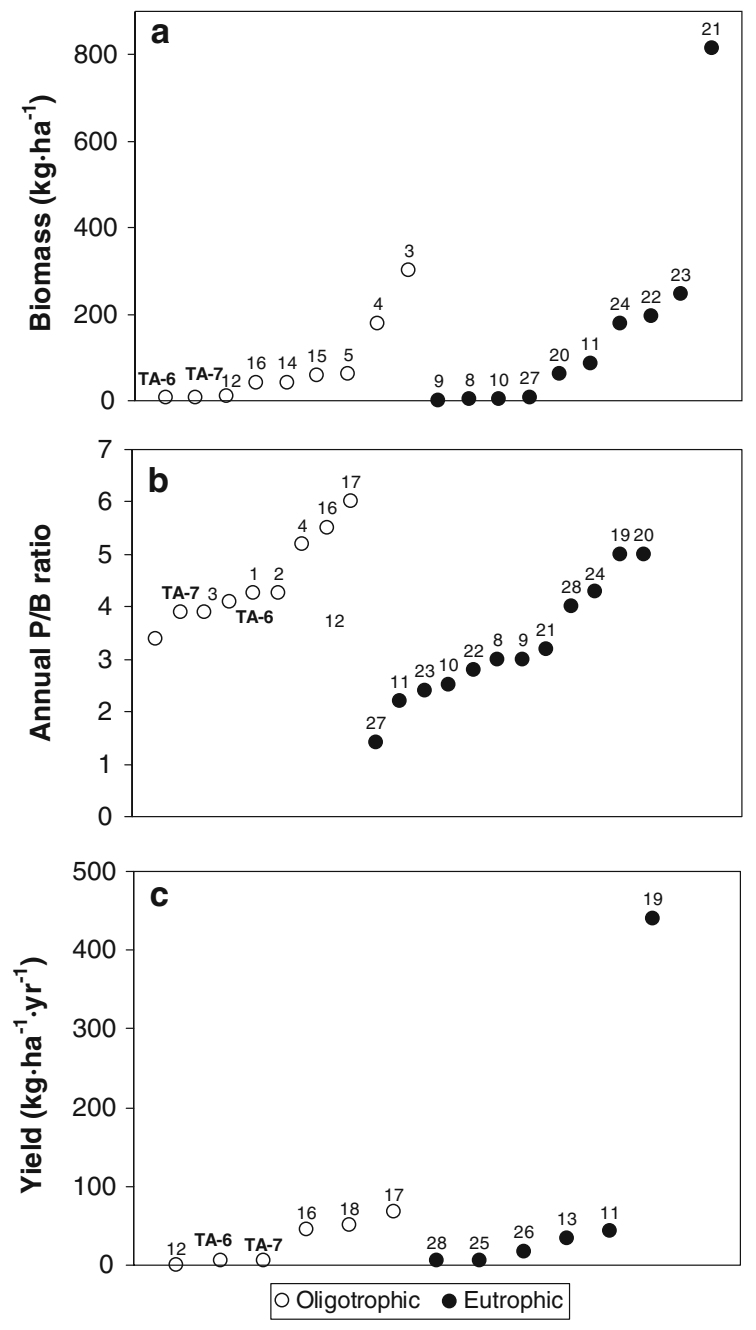

Fig. 6 Overview of a biomass, $\mathbf{b}$ annual $P / B$ ratios, and $\mathbf{c}$ yield of small planktivorous fish taxa of 17 tropical lakes and reservoirs varying in trophic status (oligotrophic/mesotrophic, eutrophic). For each lake only the taxon with the highest yield is given; the estimated maximum sustainable yield for the two barbs of Lake Tana is given for comparison. Fish taxa of each lake/reservoir are indicated by a reference number. For names of fish taxa, names of reservoirs and lakes and authorities see Table 3. Barbs of Lake Tana are indicated by TA

Malawi (\# 12), and the Indian glassfish in Lake Veli in S. India (\# 27). The highest biomass observed (approximately $800 \mathrm{~kg} \mathrm{ha}^{-1}$ ) was a phytoplanktivorous cyprinid in the eutrophic reservoir Tissawewa in Sri Lanka (\# 21). For all other fish taxa $(n=13)$ biomass values ranged between 40 and $300 \mathrm{~kg} \mathrm{ha}^{-1}$. Within this range, trophic state seemed to have no effect on the biomass of the fish taxa (Fig. 6a).
Productivity (annual $P / B$ ratio) of small fish taxa $(n=20)$ varied from 1.4 for the Indian glassfish in the S. Indian Lake Veli (\#27) to 6.0 for the clupeid Limnothrissa miodon in Kariba reservoir (\# 17) (Table 3; Fig. 6b). The estimated $P / B$ ratios of the small Barbus species from Lake Tana (\# TA-6, TA-7) of 3.1-4.7 fall within the range of values of other small cyprinids (\# 12, 21, 22, 23 and 24) and are relatively high in comparison with most other cyprinid taxa. Most often the clupeids (\# 1, 2, 3, 16, 17 19, 20, 28) and the characid Alestes spp. (\# 4) have a higher productivity than the cyprinid taxa. Hence, productivity seems to depend predominantly on the taxonomic position of the fish and less on the trophic status of the waterbody the fish inhabits.

Limiting factors for the Barbus production in lake Tana

Since several oligotrophic/mesotrophic lakes are able to support much higher biomass stocks of small fish taxa than Lake Tana (Fig. 6a), it seems plausible that Barbus stocks in Lake Tana are either bottom-up limited by their resources or top-down limited by predation. At first glance it seems unlikely that the Barbus spp. are limited by the zooplankton production because only about $29 \%$ of the zooplankton production is consumed by them. Apart from the two Barbus spp. only juvenile labeobarbs of all species, and adult Labeobarbus brevicephalus, are zooplanktivores (Nagelkerke \& Sibbing, 2000). The latter species represents approximately one-third of the Labeobarbus stock in the lake (Palstra et al., 2004) and consumes only about $1 \%$ of the zooplankton production annually.

This poor zooplankton utilisation can be caused by morphological restrictions of the zooplanktivore, or because of characteristic of the zooplankton individuals (e.g. small size, escape behaviour). The size of the zooplankton in Lake Tana is relatively large for a tropical lake, which is favourable for small zooplanktivores (Ariyaratne et al., 2008). The main reason for the poor zooplankton utilisation would then not be size, but probably the escape behaviour of especially the calanoid copepods (Thermodiaptomus galebi). Calanoid copepods represent on average 57\% of the total zooplankton production in Lake Tana (Table 2), but in the barb's diets they only represent 2.7 and $9.6 \%$ of the zooplankton for B. tanapelagius 
Table 3 Overview of small predominantly planktivorous fish taxa of 17 tropical lakes and reservoirs in Africa and Asia of which biomass, yield, and/or productivity $(P / B)$ are known

\begin{tabular}{|c|c|c|c|}
\hline$\#$ & Water body & Taxon & References \\
\hline 1 & L. Tanganyika & Limnothrissa miodon & Pearce (1988) \\
\hline 2 & & Stolothrissa tanganicae & Roest (1978) \\
\hline 3 & & Clupeids & Marshall (1995), Sarvala et al. (1999) \\
\hline 4 & L. Turkana & Alestes spp. & Kolding (1993) \\
\hline 5 & L. Kivu & Clupeids & Marshall (1995) \\
\hline 6 & L. Tana & Barbus humilis & This study \\
\hline 7 & & Barbus tanapelagius & This study \\
\hline 8 & L. Victoria & Benthivorous haplochromines & Moreau (1995) \\
\hline 9 & & Planktivorous haplochromines & Moreau (1995) \\
\hline 10 & & Predatory haplochromines & Moreau (1995) \\
\hline 11 & & Rastrineobola argentea & Moreau (1995), Pitcher et al. (1996) \\
\hline 12 & L. Malawi & Engraulicypris sardella & Degnbol (1993) \\
\hline 13 & L. Chilwa & Barbus paludinosus & Furse et al. (1979) \\
\hline 14 & Cahora Bassa reservoir & Clupeids & Marshall (1995) \\
\hline 15 & Kariba reservoir & Clupeids & Marshall (1995) \\
\hline 16 & & Limnothrissa miodon & Moreau et al. (1997) \\
\hline 17 & & Limnothrissa miodon & Marshall (1995), Machena et al. (1993) \\
\hline 18 & Nam Ngum Reservoir & Clupeichthys aesarnensis & Mattson et al. (2001) \\
\hline 19 & L. Taal & Sardinella tawilis & Baluyut (1999) \\
\hline 20 & Parakrama Samudra Res. & Ehirava fluviatilis & Duncan (1999) \\
\hline 21 & Tissawewa reservoir & Amblypharyngodon melettinus & Pet et al. (1996) \\
\hline 22 & & Barbus chola & Pet et al. (1996) \\
\hline 23 & & Barbus dorsalis & Pet et al. (1996) \\
\hline 24 & & Rasbora daniconius & Pet et al. (1996) \\
\hline 25 & Sirikit reservoir & Clupeichthys aesarnensis & EGAT (1991) \\
\hline 26 & Sirindhorn reservoir & Clupeichthys aesarnensis & EGAT (1991) \\
\hline 27 & L. Veli & Chanda ranga & Aravindan (1993) \\
\hline 28 & Ubolratana reservoir & Clupeichthys aesarnensis & Chookajorn et al. (1994) \\
\hline
\end{tabular}

See also Fig. 6

and B. humilis, respectively (Dejen et al., 2006a). Catching calanoids is challenging for small planktivorous fish since these copepods are fast swimmers and therefore have better chances to escape predation than cyclopoid copepods and cladocerans (Drenner \& McComas, 1984). Apparently, both Barbus spp. are not well suited to prey on these fast-moving zooplankton species, in contrast to many freshwater clupeids that successfully feed on calanoid copepods (Ariyaratne et al., 2008). An evolutionary reason for this might be that the planktivory of the small Barbus species is a relatively novel evolutionary development, since they originate from riverine ancestors, which were not specialised zooplanktivores. In contrast, freshwater clupeids have ancestors of marine origin, which probably already were specialised zooplanktivores (Ariyaratne et al., 2008). This means that the food available for the small barbs is predominantly limited to cladocerans and cyclopoid copepods, amounting to $43 \%$ of the zooplankton production and resulting in a potential production of zooplanktivorous fish of $79 \mathrm{~kg} \mathrm{ha}^{-1}$ year $^{-1}$. This number is much closer to the estimated $52.9 \mathrm{~kg} \mathrm{ha}^{-1}$ year $^{-1}$ (Table 1), than the $185 \mathrm{~kg} \mathrm{ha}^{-1}$ year $^{-1}$ of potential zooplanktivore production when calanoids are included in the equation. The densities of cladocerans and cyclopoid copepods showed large fluctuations during the year (Dejen et al., 2004). It is therefore 
likely that food was limiting growth and production of the two Barbus spp. during relatively short periods when cyclopoid copepod and cladoceran densities were low.

Annually the piscivorous labeobarbs consume about $29 \mathrm{~kg}$ fresh wt ha ${ }^{-1}$ of small barbs, which corresponds to $56 \%$ of the small barb production. This seems a low predation pressure, but there are also other predators of the small Barbus species in the lake, such as the common C. gariepinus and an array of bird species, such as terns (Chlidonias spp.), gulls (mainly Larus spp.), African darter (Anhinga rufa), long-tailed cormorant (Phalacrocorax africanus) and several heron species (mainly Egretta spp.; Nagelkerke, 1997). The piscivorous birds will be especially effective during the period of low water levels at the end of the dry season in May-June when water levels are 2.0-2.5 m lower than during the rainy season (Wondie et al., 2007). This could lead to increased mortality during the dry season. It therefore seems likely that at certain times in the year Barbus production was limited by either the availability of cladocerans and cyclopoid copepods, or by increased predation by birds.

Fisheries management aspects

We compared the estimated MSY of the small barbs of Lake Tana (TA) with 10 fisheries on small fish taxa from other tropical lakes and reservoirs (Table 3; Fig. 6c). The highest recorded yield was for a clupeid species (Sardinella tawilis) in a eutrophic crater lake in Philippines (\# 19), all other values were much lower, ranging between 0.1 and $68 \mathrm{~kg}$ fresh wt ha ${ }^{-1}$ year $^{-1}$. The small cyprinid Rastrineobola argentea from eutrophic L. Victoria (\# 11) showed similar yields as clupeids from oligotrophic/mesotrophic lakes in Africa and Asia (\# 16, 17, 18) and was much higher than the predicted yield of the two small barbs from the oligotrophic/ mesotrophic Lake Tana. The predicted yield for the two small barbs of Lake Tana falls within the same range as the realised yields of the small cyprinid Engraulicypris sardella in oligotrophic L. Malawi (\# 12) and of the small clupeid Clupeichthys aesarnensis in three Thai reservoirs (\# 25, 26, 28). This suggests that also in Lake Tana such a fishery on small barbs could be feasible if the existing fisheries, which focuses on Nile tilapia, African catfish and labeobarbs (de Graaf et al., 2006), are not endangered.

Conservation of the existing fisheries resources is the primary concern for managers of the Lake Tana fishery (Zikre Hig, 2003). One of the major problems at the moment is over-exploitation of the large Labeobarbus species (de Graaf et al., 2006). The exploitation of small cyprinids, low in the food web might alleviate this problem, although care should be taken not to over-exploit the food base of the piscivorous species of Lake Tana. In order to evaluate the viability of a fishery on the small Barbus species a first estimate of the MSY is important. We estimated for the whole of Lake Tana an MSY of 1,000-2,300 $t$ fresh wt year ${ }^{-1}$ for B. humilis, and 1,200-3,400 t fresh wt year ${ }^{-1}$ for B. tanapelagius.

Since the biomass of small barbs is relatively high in the sublittoral (mean $28.6 \mathrm{~kg}$ fresh wt ha ${ }^{-1}$ ), which is easily accessible for artisanal fishermen in unmotorised boats, a marginal fishery on small barbs may be possible here. The sub-littoral accounts for $20 \%$ of the lake surface, resulting in an estimated MSY of both species of about 1,800 $t$ fresh wt year ${ }^{-1}$. Despite the biological potential for a subsidiary fishery for small barbs in the sub-littoral zone in Lake Tana, we advise to be cautious in promoting this fishery, because the sub-littoral area is also the main habitat of juvenile Labeobarbus species (Dejen et al., 2006a), and because the small barb species form the main food base for the piscivorous Labeobarbus species. We therefore recommend first an experimental fishery under strict control of fisheries managers of the Amhara Region Agricultural Research Institute (ARARI) in close cooperation with the Bureau of Agriculture and Rural Development (BoARD) and evaluation of these results before a decision is made on granting permission for a fishery on small barbs in Lake Tana.

Acknowledgements The authors would like to thank the Ethiopian Agricultural Research Organization (EARO) and the Amhara Region Agricultural Research Institute (ARARI) for facilitating the current small barbs project. The support obtained from fishermen and laboratory assistants in the Bahir Dar area is highly appreciated. Our thanks are also due to Jan Osse, Wim van Densen, Marcel Machiels, Upali Amarasinghe and three anonymous reviewers for their valuable comments. The study was funded by the Netherlands Foundation for the Advancement of Tropical Research, NWO-WOTRO project WB 84-480, by the 
Interchurch Foundation Ethiopia-Eritrea (Urk), the SchureBeijerinck-Popping Foundation and the International Foundation for Science (Grant No. A/3056-1). Publication No. 3997 of the Netherlands Institute of Ecology (NIOOKNAW).

Open Access This article is distributed under the terms of the Creative Commons Attribution Noncommercial License which permits any noncommercial use, distribution, and reproduction in any medium, provided the original author(s) and source are credited.

\section{References}

Allen, K. F., 1971. Relation between production and biomass. Journal of Fisheries Research Board of Canada 20: 15731581 .

Amarasinghe, U. S., 2002. The fishery and population dynamics of Oreochromis mossambicus and Oreochromis niloticus (Osteichthyes, Cichlidae) in a shallow irrigation reservoir in Sri Lanka. Asian Fisheries Science 15: 7-20.

Amarasinghe, U. S. \& S. S. De Silva, 1992. Population dynamics of Oreochromis mossambicus and O. niloticus (Cichlidae) in two reservoirs in Sri Lanka. Asian Fisheries Science 5: 37-61.

Amarasinghe, P. B., J. Vijverberg \& M. Boersma, 1997. Production biology of copepods and cladocerans in three south-east Sri Lankan low-land reservoirs and its comparison to other tropical freshwater bodies. Hydrobiologia 350: 145-162.

Amarasinghe, P. B., M. G. Ariyaratne, T. Chitapalapong \& J. Vijverberg, 2008. Production, biomass and productivity of copepods and cladocerans in south-east Asian water bodies and the carrying capacity for zooplanktivorous fish. In Schiemer, F., D. Simon, U. S. Amarasinghe \& J. Moreau (eds), Aquatic Ecosystems and Development: Comparative Asian Perspectives. Margraf and Backhuys Publishers, Germany, The Netherlands: 173-194.

Aravindan, C. M., 1993. Preliminary trophic model of Veli Lake, southern India. In Christensen, V. \& D. Pauly (eds), Trophic Models of Aquatic Ecosystems. ICLARM Conference Proceedings 26: 87-89.

Ariyaratne, M. G., P. B. Amarasinghe, N. C. Lopez, M. Kakkaeo \& J. Vijverberg, 2008. Selective feeding of small zooplanktivorous pelagic fish species in South-east Asian reservoirs (Sri Lanka, Thailand) and Lake Taal (Philippines). In Schiemer, F., D. Simon, U. S. Amarasinghe \& J. Moreau (eds), Aquatic Ecosystems and Development: Comparative Asian Perspectives. Margraf and Backhuys Publishers, Germany, The Netherlands: 235-248.

Baluyut, E. A., 1999. Introduction and fish stocking in lakes and reservoirs in Southeast Asia: a review. In van Densen, W. L. T. \& M. J. Morris (eds), Fish and Fisheries of Lakes and Reservoirs in Southeast Asia and Africa. Westbury Publishing, Otley, England: 117-141.

Beddington, J. R. \& J. G. Cooke, 1983. On the Potential Yield of Fish Stocks. FAO Fish. Technical Paper 242.
Chookajorn, T., Y. Leenanond, J. Moreau \& B. Sricharoendam, 1994. Evolution of trophic relationships in Ubolratana reservoir (Thailand) as described using a multispecies trophic model. Asian Fisheries Science 7: 201-213.

de Angelis, D. L., 1992. Dynamics of Nutrient Cycling and Food Webs. Chapman and Hall, London.

Degnbol, P., 1993. The pelagic zone of central Lake Malawia trophic box model. In Christensen, V. \& D. Pauly (eds), Trophic Models of Aquatic Ecosystems. ICLARM Conference Proceedings 26: 110-115.

de Graaf, M., E. Dejen, J. W. M. Osse \& F. A. Sibbing, 2003. Ecological differentiation among the eight piscivores within the Barbus species flock (Pisces; Cyprinidae) of Lake Tana (Ethiopia). In de Graaf, M., Lake Tana's Piscivorous Barbus (Cyprinidae, Ethiopia): Ecology, Evolution, Exploitation. PhD Thesis, Wageningen University, Wageningen, The Netherlands: 51-82.

de Graaf, M., P. A. M. van Zwieten, M. A. M. Machiels, E. Lemma, T. Wudneh, E. Dejen \& F. A. Sibbing, 2006. Vulnerability to a small-scale commercial fishery of Lake Tana's (Ethiopia) endemic Labeobarbus compared with African catfish and Nile tilapia: an example of recruitment-overfishing? Fisheries Research 82: 304-318.

de Graaf, M., E. Dejen, J. W. M. Osse \& F. A. Sibbing, 2008. Adaptive radiation of lake Tana's (Ethiopia) Labeobarbus species flock (Pisces, Cyprinidae). Marine and Freshwater Research 59: 391-407.

Dejen, E., J. Vijverberg, L. A. J. Nagelkerke \& F. A. Sibbing, 2004. Temporal and spatial distribution of microcrustacean zooplankton in relation to turbidity and other environmental factors in a large tropical lake (L. Tana, Ethiopia). Hydrobiologia 513: 39-49.

Dejen, E., J. Vijverberg, M. de Graaf \& F. A. Sibbing, $2006 a$. Predicting and testing resource partitioning in a tropical fish assemblage of zooplanktivorous barbs: an ecomorphological approach. Journal of Fish Biology 69: 13561378.

Dejen, E., J. Vijverberg \& F. A. Sibbing, 2006b. Spatial and temporal variation of cestode infection and its effects on two small barbs (Barbus humilis and B. tanapelagius) in Lake Tana, Ethiopia. Hydrobiologia 556: 109-117.

Drenner, R. W. \& S. R. McComas, 1984. The role of zooplankter escape ability and fish size selectivity in the selective feeding and impact of planktivorous fish. In Taub, F. B. (ed.), Lakes and Reservoirs: Ecosystems of the World. Elsevier, Amsterdam: 587-593.

Duncan, A., 1999. Pelagic fish and fisheries in Asian and African lakes and reservoirs. In van Densen, W. L. T. \& M. J. Morris (eds), Fish and Fisheries of Lakes and Reservoirs in Southeast Asia and Africa. Westbury Publishing, Otley, England: 347-382.

EGAT, 1991. Fisheries Statistical Report of EGAT Reservoirs, for Fiscal Year 1990 (in Thai). Chemical and Analysis Department, Electricity Generating Authority of Thailand, Bangkok, Thailand.

Fournier, D. A., J. Hampton \& J. R. Sibert, 1998. MULTIFANCL: a length-based, age-structured model for fisheries stock assessment, with application to South Pacific albacore, Thunnus alalunga. Canadian Journal of Fisheries and Aquatic Science 55: 2105-2116. 
Furse, M. T., R. C. Kirk, P. R. Morgan \& D. Tweddle, 1979. Fishes: distribution and biology in relation to changes. In Kalk, M., A. J. McLachlan \& C. Howard-Williams (eds), Lake Chilwa: Studies of Change in a Tropical Ecosystem. Monographiae Biologicae 35. Dr W. Junk, The Hague: 175-208.

Gayanilo, F. C., P. Sparre \& D. Pauly, 2002. FiSAT II User's Guide. FAO, Rome.

Gulland, J. A., 1971. The Fish Resources of the Ocean. Fishing News Books Ltd., West Byfleet, Surrey, England.

Kolding, J., 1993. Trophic interrelationships and community structure at two different periods of Lake Turkana, Kenya: a comparison using the ECOPATH II box model. In Christensen, V. \& D. Pauly (eds), Trophic Models of Aquatic Ecosystems. ICLARM Conference Proceedings 26: 116-123.

Machena, C., J. Kolding \& R. A. Sayanga, 1993. A preliminary assessment of the trophic structure of Lake Kariba, Africa. In Christensen, V. \& D. Pauly (eds), Trophic Models of Aquatic Ecosystems. ICLARM Conference Proceedings 26: 130-137.

Marshall, B. E., 1995. Why is Limnothrissa miodon such a successful introduced species and is there anywhere else we should put it? In Pitcher, T. J. \& P. J. B. Hart (eds), The Impact of Species Changes in African Lakes. Chapman and Hall, London: 527-545.

Mattson, N. S., V. Balavong, H. Nilsson, S. Phounsavath \& W. D. Hartmann, 2001. Changes in fisheries yield and catch composition at the Nam Ngum Reservoir, Lao PDR. In De Silva, S. S. (ed.), Reservoir and Culture-Based Fisheries: Biology and Management. ACIAR 98, Canberra: 48-55.

Moreau, J., 1995. Analysis of species changes in Lake Victoria using ECOPATH, a multispecies trophic model. In Pitcher, T. J. \& P. J. B. Hart (eds), The Impact of Species Changes in African Lakes. Chapman and Hall, London: 137-161.

Moreau, J., G. Cronberg, I. Games, K. Hustler, N. Kautsky, M. Kiibus, C. Machena \& B. Marshall, 1997. Biomass flows in Lake Kariba, towards an ecosytem's approach. In Moreau, J. (ed.), Advances in the Ecology of Lake Kariba. University of Zimbabwe Publications, Harare, Zimbabwe: 219-230.

Nagelkerke, L. A. J., 1997. The Barbs of Lake Tana, Ethiopia: Morphological Diversity and its Implications for Taxonomy, Trophic Resource Partitioning, and Fisheries. PhD Thesis, Agricultural University Wageningen, Wageningen, The Netherlands.

Nagelkerke, L. A. J. \& F. A. Sibbing, 2000. The large barbs (Barbus spp., Cyprinidae, Teleostei) of Lake Tana (Ethiopia), with a description of a new species, Barbus osseensis. Netherlands Journal of Zoology 50: 179-214.

Nagelkerke, L. A. J., F. A. Sibbing, J. G. M. van den Boogaart, E. H. R. R. Lammens \& J. W. M. Osse, 1994. The barbs (Barbus spp.) of Lake Tana: a forgotten species flock? Environmental Biology of Fishes 39: 1-22.

Palstra, A. P., M. de Graaf \& F. A. Sibbing, 2004. Riverine spawning and reproductive segregation in a lacustrine cyprinid species flock, facilitated by homing? Animal Biology 54: 393-415.
Pauly, D., 1984. Fish Population Dynamics in Tropical Waters: A Manual for use for Programmable Calculators. ICLARM Studies and Reviews 8, Manila.

Pauly, D. \& J. L. Munro, 1984. Once more on the comparison of growth in fish and invertebrates. Fishbyte 2: 21 .

Pearce, M. J., 1988. A Description and Stock Assessment of the Pelagic Fishery in the South East Arm of Zambian Waters of Lake Tanganyika. Report to the Overseas Development Administration, London.

Pet, J. S., G. J. M. Gevers, W. L. T. van Densen \& J. Vijverberg, 1996. Management options for complete utilisation of the biological fish production in Sri Lankan reservoirs. Ecology of Freshwater Fish 5: 1-14.

Pitcher, T. J., A. Bundy \& E. N. William, 1996. The fishery for Rastrineobola argentea in Lake Victoria: estimation of potential yields using a new approximate model based on primary production. Fisheries Research 28: 133-149.

Post, J. R. \& J. A. Lee, 1996. Metabolic ontogeny of teleost fishes. Canadian Journal of Fisheries and Aquatic Sciences 53: 910-923.

Roest, F. C., 1978. Stolothrissa tanganicae: population dynamics, biomass evolution and life history in the Burundi waters of Lake Tanganyika. CIFA Technical Report 5: 42-62.

Sarvala, J., K. Salonen, M. Järvinen, E. Aro, T. Huttula, P. Kotilainen, H. Kurki, V. Langenberg, P. Mannini, A. Peltonen, P.-D. Plisnier, I. Vuorinen, H. Mölsä \& O. V. Lindqvist, 1999. Trophic structure of Lake Tanganyika: carbon flows in the pelagic food webs. Hydrobiologia 407: 149-173.

Sarvala, J., M. Tarvainen, K. Salonen \& H. Mölsä, 2002. Pelagic food web as the basis of fisheries in Lake Tanganyika: a bioenergetic modeling analysis. Aquatic Ecosystem Health and Management 5: 283-292.

Sibbing, F. A. \& L. A. J. Nagelkerke, 2001. Resource partitioning by Lake Tana barbs predicted from fish morphometrics and prey characteristics. Reviews in Fish Biology and Fisheries 10: 393-437.

Sparre, P. \& S. C. Venema, 1998. Introduction to tropical fish stock assessment. Part 1. Manual. FAO Fisheries Technical Paper 306.1, Rev. 2. FAO, Rome.

Vijverberg, J., M. Boersma, W. L. T. van Densen, W. Hoogenboezem, E. H. R. R. Lammens \& W. M. Mooij, 1990. Seasonal variation in the interactions between piscivorous fish, planktivorous fish and zooplankton in a shallow eutrophic lake. Hydrobiologia 207: 279-286.

Wondie, A., S. Mengistu, J. Vijverberg \& E. Dejen, 2007. Seasonal variation in primary production of a large high altitude tropical lake (L. Tana, Ethiopia): effects of nutrient availability and water transparency. Aquatic Ecology 41: 195-207.

Wudneh, T., 1998. Biology and Management of Fish Stocks in Bahir Dar Gulf, Lake Tana, Ethiopia. PhD Thesis, Wageningen Agricultural University, Wageningen, The Netherlands.

Zikre Hig, 2003. The Amhara National Regional State Fisheries Development, Prevention and its Utilization. Proclamation 92/2003. The Council of the Amhara National Regional State, Bahir Dar, Ethiopia. 